\title{
Preparation of Biochar via Dry Torrefaction of Wood Meal in a Batch Reactor under Pressure and its Co-Combustion Behavior with Anthracite Coal
}

\author{
Wei Yang, ${ }^{\text {a }}$ Fan Yang, ${ }^{\mathrm{a}}$ Xu Zhang, ${ }^{\mathrm{a}}$ Pengfei Zhu, ${ }^{\mathrm{a}}$ Huanghu Peng, ${ }^{\mathrm{a}}$ Zezhou Chen, ${ }^{\mathrm{a}}$ \\ Lei Che, ${ }^{\mathrm{b}}$ Shouxin $\mathrm{Zhu},{ }^{\mathrm{a}, *}$ and Shengji $\mathrm{Wu}^{\mathrm{a}, *}$
}

\begin{abstract}
Biochar was prepared by dry torrefaction of wood meal in a batch reactor under pressurized conditions. The biochar prepared at $340{ }^{\circ} \mathrm{C}$ (WMB-340) showed a higher heating value (HHV) of $30.5 \mathrm{MJ} / \mathrm{kg}$, and it was employed to co-combust with anthracite coal (AC) with the HHV of $28 \mathrm{MJ} / \mathrm{kg}$. The WMB-340 underwent two combustion stages, while the AC only showed one combustion stage. The combustion of AC was promoted by WMB-340 at temperatures higher than $490{ }^{\circ} \mathrm{C}$, indicating the existence of a synergetic effect during co-combustion. Blending AC with 10\% WMB-340 had no obvious effect on the combustion stage of AC. However, three combustion stages existed when blending more than $10 \%$ WMB-340 with AC. The activation energy of AC blended with $10 \%$ WMB-340 was $84.5 \mathrm{~kJ}$ $\mathrm{mol}^{-1}$, much lower than that of $\mathrm{AC}\left(179.3 \mathrm{~kJ} \mathrm{~mol}^{-1}\right)$, indicating a lower energy for initialization of the blend. Therefore, AC blended with $10 \%$ WMB-340 was the optimal ratio for co-combustion in this study.
\end{abstract}

Keywords: Dry torrefaction; Fuel properties; Wood meal biochar; Anthracite coal; Co-combustion behavior

Contact information: a: College of Engineering, Huzhou University, No. 759, East 2nd Road, Huzhou 313000 China; b: Zhejiang ECO Environmental Technology Co., LTD. No. 1188, Wuxing District, Huzhou 313000 China; *Corresponding author:wu_shengji@hotmail.com (WuSJ); zsx@zjhu.edu.cn (Zhu SX)

\section{INTRODUCTION}

Due to the depletion of fossil fuels and growing concerns about greenhouse gas emissions and the potential toxic elements (i.e., mercury, lead, and arsenic) released during coal combustion (Fu et al. 2019), the utilization of renewable energy resources as an alternative to conventional fossil fuels has attracted increasing attention worldwide. Biomass that accounted for $15 \%$ of the worldwide primary energy consumption (Liu et al. 2016), is one of the most promising alternative energy resources to fossil fuels, because of its abundance, carbon neutrality (carbon dioxide captured through photosynthesis can offset that emitted during combustion of biomass), and low sulfur content (Yang et al. 2017; Pang 2019). Replacement of coal by biomass is an effective approach to control the carbon dioxide emissions and avoid methane release from landfill biomass (Li et al. 2012; Poulsen and Adelard 2016). However, the high moisture content and low higher heating value (HHV) of biomass led to low thermal efficiency during co-combustion. The amount of heat released was very low, and some of the heat was used to evaporate water retained in biomass, which limited the direct combustion of raw biomass with coal (Li et al. 2018).

Biochar is a promising biofuel to co-combust with coal, due to its better fuel properties compared to biomass feedstock. Various methods have been proposed to produce biochar from biomass. One of them is dry torrefaction, a thermal degradation process that is conducted at 200 to $300{ }^{\circ} \mathrm{C}$ in an inert or limited-oxygen atmosphere at 
constant atmospheric pressure or elevated pressure. The properties of torrefied biomass (biochar) depend on various factors, i.e., biomass type, temperature, pressure, and pretreatment method. For example, Chen et al. (2015) torrefied microalgae at 200 to 300 ${ }^{\circ} \mathrm{C}$, and the HHV of obtained biochar were similar to those of commercial coals. Li et al. (2016) torrefied pine and poplar under $\mathrm{CO}_{2}$ conditions and the prepared biochar had similar $\mathrm{HHV}$ and $\mathrm{H} / \mathrm{C}$ and $\mathrm{O} / \mathrm{C}$ atomic ratios to lignite. Gan et al. (2019) found that particle size had a major effect on the HHV of biochar during torrefaction of de-oiled Jatropha seed kernels; those with a smaller particle size showed greater improvements in HHV. Although the fuel properties of biomass could be drastically improved after torrefaction at high temperatures, the yield of biochar was reduced dramatically, especially when the torrefaction temperature was higher than $280{ }^{\circ} \mathrm{C}$, resulting in the significant decrease in energy yield. For example, the energy yields of Leucaena and wheat straw were reduced to $61.21 \%$ and $65.8 \%$ of the starting amounts after torrefaction at 275 and $290{ }^{\circ} \mathrm{C}$, respectively (Dai et al. 2019). Although the woody biomass showed higher energy yield than herbaceous biomass after torrefaction, the HHV of biochar could only reach the level of low-rank coal such as lignite, even after torrefaction at $300{ }^{\circ} \mathrm{C}$. Thus, it is necessary to improve HHV and energy yield of biochar at high reaction temperatures. The biomass was mainly released as volatiles during dry torrefaction; the HHV of biochar was dominated by the carbon content. If the carbon in volatiles could be re-captured during torrefaction, then the HHV of biochar would be greatly improved. It was reported that pyrolysis of biomass under pressurized conditions could help trap volatiles, especially heavy molecules that produced char and $\mathrm{CO}_{2}$ (Mahinpey et al. 2009). Therefore, dry torrefaction of biomass was conducted under pressure to improve the HHV and energy yield of biochar.

To promote the co-combustion efficiency of biochar and coal, the combustion behavior should be determined. Better combustion performance could be obtained through adjusting the ratio of biochar to coal, and coal blended with less than $50 \%$ biochar always showed better combustion behaviors (i.e., high combustion reactivity and low ignition index) than those with higher biochar contents (Sahu et al. 2010; Toptas et al. 2015). However, synergistic effect between biochar and coal occurred during co-combustion, which needed to be investigated in greater depth in order to further improve their cocombustion efficiency. In this study, wood meal, a waste produced in wood processing industry, was employed to produce biochar via dry torrefaction under pressurized and oxygen-limited conditions. Anthracite coal (AC) is a typical high-quality coal widely used as fuel supplied to boilers due to its low volatile content and high fixed carbon content (Ouyang et al. 2013). However, it has difficulties in ignition, stabilization, and burn out, resulting in low combustion efficiency. Therefore, wood meal biochar (WMB) with relatively low ignition temperature was chosen to co-combusted with $\mathrm{AC}$ to improve the combustion characteristics of $\mathrm{AC}$. The fuel properties of $\mathrm{WMB}$ and the synergistic effect between WMB and AC during co-combustion were studied in terms of HHV, energy yield, combustion kinetics, and the temperatures of ignition $\left(T_{i}\right)$, peak $\left(T_{p}\right)$, and burnout $\left(T_{b}\right)$.

\section{EXPERIMENTAL}

\section{Materials}

The wood meal and AC were provided by a local wood processing company and a power plant, respectively. Before the experiment, the wood meal was pulverized, sieved (with a particle size less than $0.4 \mathrm{~mm}$ ), and dried. 


\section{Dry Torrefaction of Wood Meal in a Batch Reactor under Pressure}

Dry torrefaction of wood meal was conducted in a batch reactor with a working volume of $10 \mathrm{~mL}$ under pressurized and oxygen-limited conditions. The torrefaction temperature ranged from 240 to $340{ }^{\circ} \mathrm{C}$ based on previous research, and the reaction time was $10 \mathrm{~min}$ (Li et al. 2016). In a typical experiment, $300 \mathrm{mg}$ of wood meal was charged into the reactor, which was then closed tightly. The reactor was placed into a ceramic furnace connected with a digital temperature controller. The temperature inside the reactor was monitored by inserting a thermocouple into a tube installed in the middle of the reactor. The reaction time was calculated after the temperature inside the reactor reached the desired temperature. The pressure inside the reactor was determined based on the thermal expansion of air. The reactor was immersed in an ice bath immediately after the reaction time elapsed and the WMB was collected and dried. The dried WMB was defined as WMB$x$, where " $x$ " was the torrefaction temperature. The WMB-340 was co-combusted with AC at 5 different contents $(10 \%, 20 \%, 40 \%, 60 \%$, and $80 \%)$, which were named as 10WMB90AC, 20WMB80AC, 40WMB60AC, 60WMB40AC, and 80WMB20AC, respectively.

\section{Characterization}

The functional groups and crystalline changes of the WMB were recorded via a Nicolet iS50 Fourier transform infrared spectroscope (FTIR, Thermo Fisher Scientific, MA) and a powder X-ray diffraction analyzer (XRD, Rigaku, Miniflex600, Tokyo), respectively. The elemental contents were measured via an elemental analyzer (Elementar, Vario Mircro cube, Germany). The HHV was calculated using Eq. 1 (Qian et al. 2020),

$$
\mathrm{HHV}=32.9 \mathrm{C}+162.7 \mathrm{H}-16.2 \mathrm{O}-954.4 \mathrm{~S}+1.408
$$

where $\mathrm{C}, \mathrm{H}, \mathrm{O}$, and $\mathrm{S}$ are the carbon, hydrogen, oxygen, and sulfur contents of wood meal or WMB, respectively. Energy yield was calculated according to Eq. 2:

$$
\text { Energy yield }(\%)=\mathrm{HHV}_{\text {wмB }} / \mathrm{HHV}_{\text {wood meal }} \times \mathrm{WMB} \text { mass yield }
$$

The combustion experiment was conducted via a thermogravimetric analyzer (TGA/DSC LF1600, Mettler-Toledo, Switzerland) at 35 to $800{ }^{\circ} \mathrm{C}\left(10{ }^{\circ} \mathrm{C} \mathrm{min}{ }^{-1}\right)$ under air

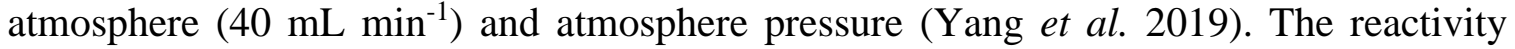
quantitatively was evaluated by reactively index $\left(R_{0.5}\right)$ according to Eq. 3,

$$
R_{0.5}=0.5 / t_{0.5}
$$

where $t 0.5$ was the time when $50 \%$ of the sample was combusted (Wang et al. 2018).

\section{Calculation of Kinetic Parameters}

Two equations were employed to determine the combustion kinetic parameters, as shown in Eqs. 4 and 5,

$$
\begin{aligned}
& -\mathrm{d} X / \mathrm{d} t=k X^{n} \\
& k=A_{1} e^{-E / R T}
\end{aligned}
$$

Replacing $k$ in Eq. 4 by Eq. 5 and taking Napierian logarithm on both sides, the Eq. 4 can be converted into the form of Eq. 6,

$$
\ln (-\mathrm{d} X / \mathrm{d} t)=\ln A_{1}-E / R T+n \ln X
$$

The definition of $X$ as $\left(m_{t}-m_{\mathrm{f}}\right) /\left(m_{0}-m_{\mathrm{f}}\right)$ and Eq. 6 can be written as 


$$
\ln \left[-1 /\left(m_{0}-m_{\mathrm{f}}\right) \mathrm{d} m_{t} / \mathrm{d} t\right]=\ln A_{1}-E / R T+n \ln \left[\left(m_{t}-m_{\mathrm{f}}\right) /\left(m_{0}-m_{\mathrm{f}}\right)\right]
$$

where $X$ is the weight ratio of reacted wood meal, AC, WMB, or blend, $t$ is the combustion time (s), $k$ is the reaction constant $\left(\mathrm{s}^{-1}\right), n$ is the reaction order, $A_{1}$ is the pre-exponential factor $\left(\mathrm{s}^{-1}\right), E$ is the activation energy $\left(\mathrm{kJ} \mathrm{mol}^{-1}\right), R$ is the universal gas constant $\left(\mathrm{kJ} \mathrm{mol}^{-1}\right.$ $\left.\mathrm{K}^{-1}\right), m_{t}$ is the weight of wood meal, $\mathrm{AC}, \mathrm{WMB}$, or blend at time $t(\mathrm{~kg})$, and $m_{0}$ and $m_{\mathrm{f}}$ are the initial and final weights $(\mathrm{kg})$ of the wood meal, $\mathrm{AC}, \mathrm{WMB}$ or blend under dry basis in each particular zone, respectively.

The form of Eq. 7 is shown in Eq. 8,

$$
y=C+D x+F z
$$

where $y, C, D, x, F$, and $z$ are $\ln \left[-1 /\left(m_{0}-m_{\mathrm{f}}\right) \mathrm{d} m_{t} / \mathrm{d} t\right], \ln A_{1},-E, 1 / R T, n$, and $\ln \left[\left(m_{t}-\right.\right.$ $\left.\left.m_{\mathrm{f}}\right) /\left(m_{0}-m_{\mathrm{f}}\right)\right]$, respectively. $C, D$, and $F$ were estimated via linear fitting of weight loss curve of sample obtained from TGA experiment by LINEST function in Microsoft Excel.

\section{RESULTS AND DISCUSSION}

\section{Yields and Physicochemical Properties of Wood Meal Biochar}

The wood meal was torrefied at various temperatures and it was found that torrefaction temperature had a great effect on the WMB yield. At a torrefaction temperature of $240{ }^{\circ} \mathrm{C}$, the yield of $\mathrm{WMB}$ was $84.9 \%$ (Table 1). The yield decreased at higher torrefaction temperatures and it decreased to $51.8 \%$ at a torrefaction temperature of 340 ${ }^{\circ} \mathrm{C}$. The decrease in WMB yield was primarily attribute to the degradation of cellulose and hemicellulose, which were relatively reactive in comparison to lignin.

Table 1. Yield, Elemental contents, Ash Content, $\mathrm{O} / \mathrm{C}$ and $\mathrm{H} / \mathrm{C}$ Atomic Ratios,

\begin{tabular}{|c|c|c|c|c|c|c|c|c|c|c|c|}
\hline Material & $\begin{array}{l}\text { Yield } \\
(\%)\end{array}$ & $\begin{array}{c}\mathrm{C} \\
(\%)\end{array}$ & $\begin{array}{l}\mathrm{H} \\
(\%)\end{array}$ & $\begin{array}{l}N \\
(\%)\end{array}$ & $\begin{array}{c}\mathrm{S} \\
(\%)\end{array}$ & $\begin{array}{l}\mathrm{O}^{\mathrm{a}} \\
(\%)\end{array}$ & $\begin{array}{c}\text { Ash } \\
\text { content } \\
(\%)\end{array}$ & $\mathrm{O} / \mathrm{C}$ & $\mathrm{H} / \mathrm{C}$ & $\begin{array}{c}\mathrm{HHV} \\
\left(\mathrm{MJ} \mathrm{kg}^{-1}\right)\end{array}$ & $\begin{array}{c}\text { Energy } \\
\text { Yield } \\
(\%)\end{array}$ \\
\hline Wood meal & - & 48.6 & 6.1 & 0.7 & 0 & 44.6 & 0.9 & 0.69 & 1.51 & 20.1 & - \\
\hline WMB-240 & 84.9 & 53.2 & 5.8 & 0.7 & 0 & 40.3 & 1.1 & 0.57 & 1.31 & 21.8 & 92.2 \\
\hline WMB-260 & 77.9 & 55.6 & 5.7 & 0.7 & 0 & 38 & 1.2 & 0.51 & 1.23 & 22.8 & 88.4 \\
\hline WMB-280 & 69.3 & 58.2 & 5.6 & 0.7 & 0 & 35.5 & 1.3 & 0.46 & 1.15 & 23.9 & 82.4 \\
\hline WMB-300 & 56.6 & 68.3 & 5.3 & 0.7 & 0 & 25.7 & 1.5 & 0.28 & 0.93 & 28.3 & 79.8 \\
\hline WMB-320 & 53.7 & 71.9 & 5.1 & 0.8 & 0 & 22.2 & 1.5 & 0.23 & 0.85 & 29.7 & 79.4 \\
\hline WMB-340 & 51.8 & 73.4 & 5.1 & 0.8 & 0 & 20.7 & 1.6 & 0.21 & 0.83 & 30.5 & 78.6 \\
\hline $\mathrm{AC}$ & - & 80.7 & 2.7 & 1.6 & 0.2 & 14.8 & 13 & 0.13 & 0.4 & 28 & - \\
\hline
\end{tabular}
Higher Heating Value, and Energy Yield of Wood Meal Biochar

The functional group and crystalline structure changes in wood meal and WMB are shown in Fig. 1. The wood meal and WMB had similar adsorption bands (Fig. 1a). The peaks attributable to $\mathrm{O}-\mathrm{H}\left(3400 \mathrm{~cm}^{-1}\right)$ and $\mathrm{C}-\mathrm{O}\left(1030 \mathrm{~cm}^{-1}\right)$ stretching vibrations in hemicellulose and cellulose, respectively, became less intense at high torrefaction temperatures (Yang et al. 2019). Similar results were also observed at the peak of the aliphatic $\mathrm{C}-\mathrm{H}$ stretching vibration, which was found at $2900 \mathrm{~cm}^{-1}$. The decrease in $\mathrm{O}-\mathrm{H}$ peak strength was primarily caused by the dehydration of carboxyl groups to form $\mathrm{C}=\mathrm{O}$ groups $\left(1720 \mathrm{~cm}^{-1}\right)$, which became stronger at higher torrefaction temperatures. The adsorption peaks at 1600,1520 , and $1420 \mathrm{~cm}^{-1}$ related to 
the monocyclic, polycyclic, and substituted aromatic groups, respectively, were present in all WMB samples, which implied a high thermal stability of the aromatic structures in lignin (Li et al. 2016). The strength of the above peaks increased as the torrefaction temperature increased, probably due to the decomposition of holocellulose and generation of aromatic linked char during torrefaction (Boon et al. 1994). In addition, the adsorption peaks of $\mathrm{C}-\mathrm{O}-\mathrm{C}$ and $\mathrm{C}-\mathrm{H}$, which existed at 1100 and $1380 \mathrm{~cm}^{-1}$, respectively, disappeared as the torrefaction temperatures increased to higher than $300{ }^{\circ} \mathrm{C}$, indicating considerable holocellulose decomposition.
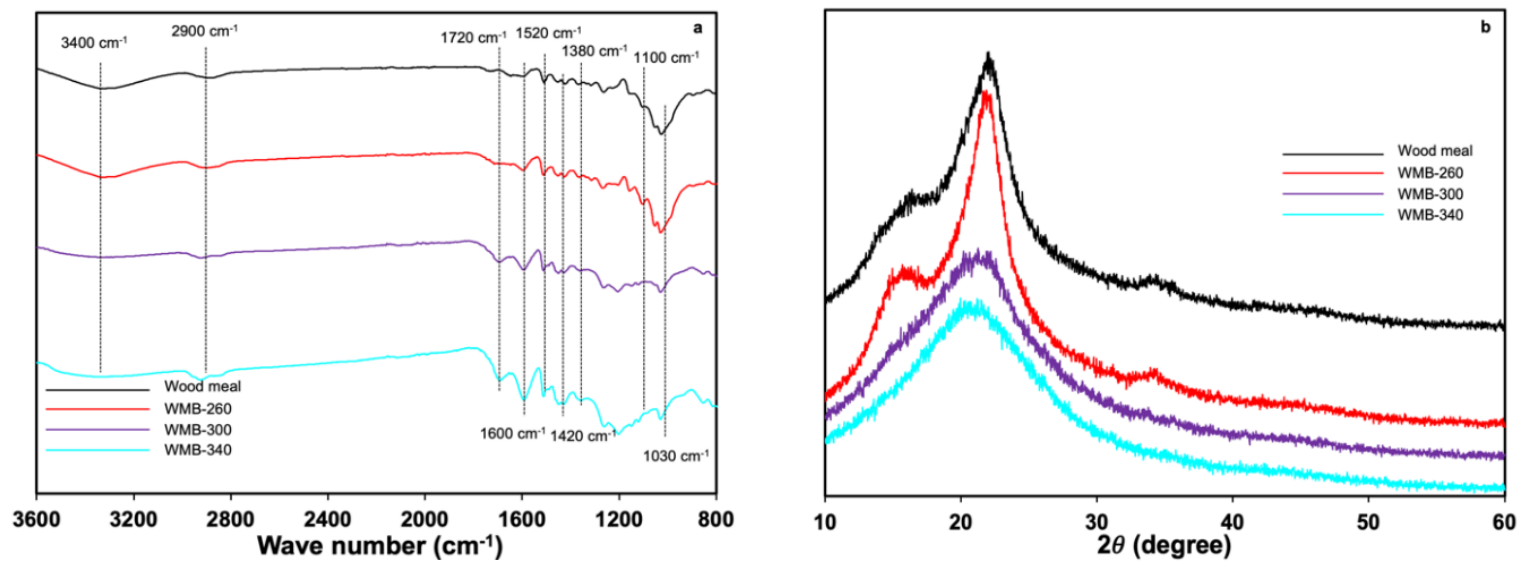

Fig. 1. (a) FTIR spectra and (b) XRD patterns of wood meal and wood meal biochar

Figure $1 \mathrm{~b}$ shows the XRD patterns of wood meal and WMB. The major peak at $2 \theta$ $=22.5^{\circ}$, which corresponds to the (200) lattice plane of the cellulose crystal, had no meaningful change at torrefaction temperatures lower than $260{ }^{\circ} \mathrm{C}$, although $22.1 \%$ of the wood meal was decomposed. However, as the torrefaction temperature reached $300{ }^{\circ} \mathrm{C}$, the peak of cellulose crystal completely disappeared and a broad diffraction peak that can be attributed to the amorphous area of WMB appeared. The disappearance of the crystalline peak was caused by the evolution and destruction of the cellulose crystalline structure during torrefaction, in accordance with the FTIR spectra of WMB.

The elemental contents of WMB are shown on Table 1. It could be observed that the carbon content of WMB was greatly increased after torrefaction, whereas the oxygen content decreased. The nitrogen and hydrogen contents of WMB showed no obvious change after torrefaction. In addition, the ash content in WMB also showed an increase with increasing torrefaction temperature. The $\mathrm{O} / \mathrm{C}$ and $\mathrm{H} / \mathrm{C}$ atomic ratios of $\mathrm{WMB}$ were among 0.21 to 0.57 and 0.83 to 1.31 , respectively, much lower than those of raw wood meal. The lower $\mathrm{O} / \mathrm{C}$ and $\mathrm{H} / \mathrm{C}$ atomic ratios of $\mathrm{WMB}$ indicated reduced energy loss, less smoke and water vapor generation during combustion. Demethanation, dehydration, and decarboxylation were the primary reactions that occurred during torrefaction of wood meal. The $\mathrm{O} / \mathrm{C}$ and $\mathrm{H} / \mathrm{C}$ atomic ratios in WMB showed a strong linear relationship $(y=1.3842 x$ $\left.+0.5328 ; r^{2}=0.9975\right)$ and moved along with dehydration line (data not shown), indicating that dehydration was the major reaction occurred during torrefaction. The WMB-340 showed much lower $\mathrm{O} / \mathrm{C}$ and $\mathrm{H} / \mathrm{C}$ atomic ratios than rape stalk derived biochar pyrolyzed at $600{ }^{\circ} \mathrm{C}$, probably due to the promotion of aromatization and carbonization degree by the pressure built in the reactor (He at al. 2018). They were also comparable to those of bituminous coal, indicating the potential to be used as a solid fuel (Huang et al. 2019). 
The HHV of WMB was calculated to evaluate the amount of heat released from WMB during combustion. The HHV of WMB significantly increased at high torrefaction temperatures, and it reached $30.5 \mathrm{MJ} \mathrm{kg}^{-1}$ at $340{ }^{\circ} \mathrm{C}$ with an improvement of $51.7 \%$ compared to raw wood meal (Table 1). The increase in HHV was caused by the formation of chemical bonds with high energy $(\mathrm{C}-\mathrm{C})$ and breaking of chemical bonds with low energy ( $\mathrm{H}-\mathrm{C}$ and $\mathrm{O}-\mathrm{C}$ ) in WMB, as evidenced by the FTIR spectra of WMB. Although the energy yield of WMB became lower at higher torrefaction temperatures, it still maintained as high yield as $78.6 \%$, even at $340{ }^{\circ} \mathrm{C}$. The energy yield of WMB-340 was comparable with those of bamboo stem (78\%) and willow (79.2\%) torrefied at 280 and 290 ${ }^{\circ} \mathrm{C}$, respectively (Dai et al. 2019). This was likely due to the suppression of wood meal volatilization by high pressure and the formation of biochar through re-capture of volatiles. The HHV of WMB-340 was much higher than those of rape stalk derived biochar $(26.19$ $\mathrm{MJ} \mathrm{kg}{ }^{-1}$ ) pyrolyzed for $30 \mathrm{~min}$ at $600{ }^{\circ} \mathrm{C}$ and pine derived biochar $\left(25.6 \mathrm{MJ} \mathrm{kg}^{-1}\right)$ torrefied at $340{ }^{\circ} \mathrm{C}$ for 30 min under carbon dioxide condition (He at al. 2018; Li et al. 2016). It was also comparable with that of Pennsylvania anthracite coal (Rover et al. 2018). Based on the above excellent fuel properties, it was concluded that dry torrefaction can be an effective process for improving the energy content of wood meal.
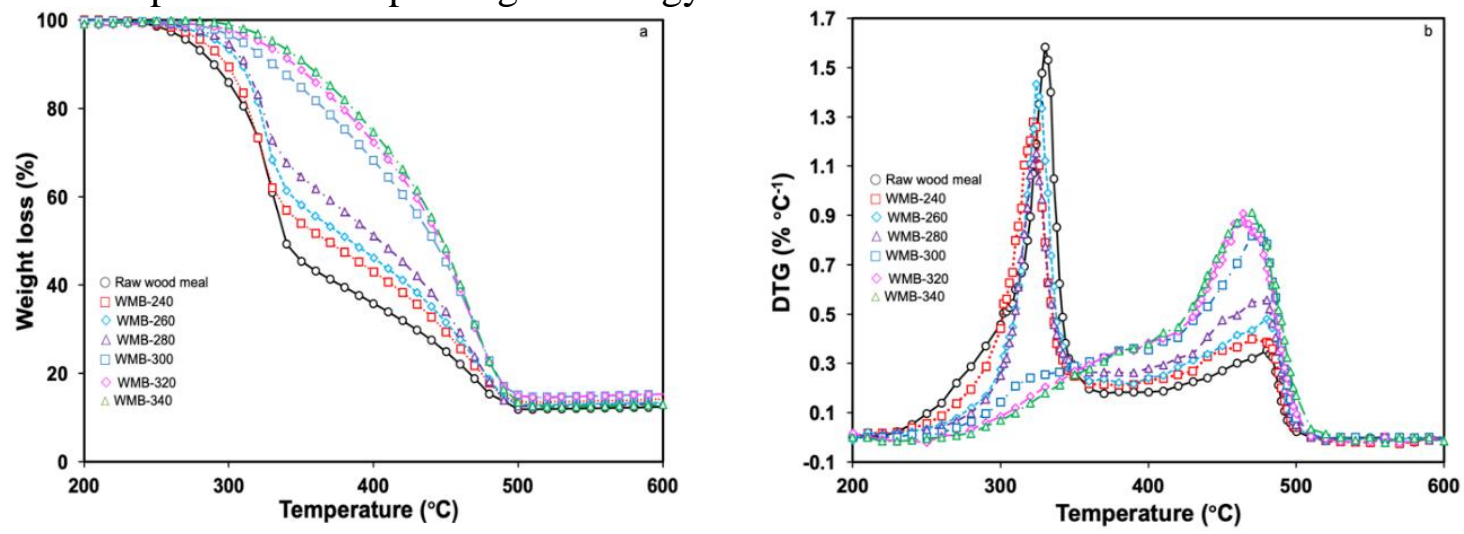

Fig. 2. (a) TGA and (b) DTG curves of raw wood meal and wood meal biochars prepared at torrefaction temperatures of $240,260,280,300,320$, and $340^{\circ} \mathrm{C}$

\section{Combustion Properties of Wood Meal and Wood Meal Biochar}

Figure 2 shows the combustion properties of wood meal and WMB. It was observed that dry torrefaction had a drastic effect on the combustion properties of wood meal. The majority of the volatiles in raw wood meal were released at 215 to $499{ }^{\circ} \mathrm{C}$, and two major combustion stages were present in the DTG curve. The first combustion stage resulted from the combustion of the relative reactive compounds in wood meal, while the second stage was caused by the combustion of lignin (Yang et al. 2019). Two peaks existed at 332 and $488{ }^{\circ} \mathrm{C}$ with the weight loss rates of 1.58 and $0.40 \%{ }^{\circ} \mathrm{C}^{-1}$, respectively. The weight loss rate of $\mathrm{WMB}$ at the first peak decreased at higher torrefaction temperatures, whereas it increased at the second peak. The decrease in the WMB weight loss rate was caused by the decomposition of holocellulose during dry torrefaction, while the increase of weight loss rate was due to the generation of aromatic linked char (Yang et al. 2019). The first peak of WMB prepared at torrefaction temperatures lower than $280{ }^{\circ} \mathrm{C}$ showed a higher weight loss rate than the second peak. However, it became lower than the weight loss rate of the second peak at the torrefaction temperature higher than $280^{\circ} \mathrm{C}$, indicating lower emissions of polycyclic aromatic hydrocarbons and CO during combustion (Khan et al. 2009). 
Table 2. Combustion Characteristics of Wood Meal, Wood Meal Biochar, Anthracite Coal, and Wood Meal Biochar Blends

\begin{tabular}{|c|c|c|c|c|}
\hline Sample & $T_{i}\left({ }^{\circ} \mathrm{C}\right)$ & $T_{p}\left({ }^{\circ} \mathrm{C}\right)$ & $T_{b}\left({ }^{\circ} \mathrm{C}\right)$ & $R_{0.5} \times 10^{-4}\left(\mathrm{~s}^{-1}\right)$ \\
\hline Wood meal & 315 & 332 & 499 & 2.8 \\
\hline WMB-240 & 310 & 321 & 509 & 2.47 \\
\hline WMB-260 & 310 & 327 & 509 & 2.4 \\
\hline WMB-280 & 307 & 324 & 509 & 2.27 \\
\hline WMB-300 & 384 & 478 & 514 & 2.1 \\
\hline WMB-320 & 406 & 467 & 514 & 2.08 \\
\hline WMB-340 & 403 & 470 & 522 & 2.06 \\
\hline Anthracite coal & 555 & 616 & 737 & 1.45 \\
\hline $10 \%$ WMB 90\% AC & 522 & 577 & 666 & 1.59 \\
\hline $20 \%$ WMB 80\% AC & 496 & 565 & 668 & 1.62 \\
\hline $40 \%$ WMB 60\% AC & 456 & 563 & 653 & 1.68 \\
\hline $60 \%$ WMB 40\% AC & 382 & 470 & 649 & 1.87 \\
\hline $80 \%$ WMB 20\% AC & 380 & 458 & 640 & 2.05 \\
\hline
\end{tabular}

The $T_{i}, T_{p}, T_{b}$, and $R_{0.5}$ of wood meal and WMB are shown on Table 2. The $T_{i}$ of WMB prepared at torrefaction temperatures lower than $280{ }^{\circ} \mathrm{C}$ was similar to wood meal. However, it was drastically improved when the torrefaction temperature increased to higher than $280^{\circ} \mathrm{C}$, probably due to the decomposition of volatiles and an increase in the aromatization degree. The higher $T_{i}$ of WMB indicated a lower risk of spontaneous ignition during fuel storage and transportation ( $\mathrm{Lu}$ et al. 2015). Similar results were also obtained in the $T_{p}$ of WMB, which also showed little change at torrefaction temperatures below 280 ${ }^{\circ} \mathrm{C}$ and shifted to higher temperatures at higher torrefaction temperatures. Meanwhile, the $R 0.5$ decreased from $2.8 \times 10^{-4}$ to $2.06 \times 10^{-4} \mathrm{~s}^{-1}$ as the torrefaction temperature increased to $340{ }^{\circ} \mathrm{C}$, indicating the reduction of reactivity, which was caused by the decomposition of reactive components. Therefore, a higher combustion temperature was needed to burn the WMB obtained at torrefaction temperature higher than $280{ }^{\circ} \mathrm{C}$. In addition, the $T_{b}$ of WMB showed no obvious change, with values ranging from 499 to $522^{\circ} \mathrm{C}$. This result was likely caused by the high thermal stability of the aromatic structures in lignin, which were barely decomposed during torrefaction of wood meal.

\section{Co-combustion of WMB-340 and Anthracite Coal}

The TGA and DTG profiles of WMB-340 and AC blends are shown in Fig. 3. The AC was much more stable than WMB-340, the volatiles of which released in the temperature range of 436 to $737^{\circ} \mathrm{C}$. Only one combustion stage existed during combustion of AC. The TGA profiles of WMB-340 and AC blends were located between the individual TGA profiles of WMB-340 and AC. The volatiles in the WMB-340 and AC blends released at a lower temperature range than $\mathrm{AC}$ alone, and this range decreased as the WMB-340 ratio increased. An addition of 10\% WMB-340 with AC had no obvious effect on the DTG profile of AC, although the DTG peak shifted to a lower temperature. The DTG profiles of the $\mathrm{AC}$ and WMB-340 blends were transformed from one board combustion stage to three combustion stages as the ratio of WMB-340 increased to higher than 10\%. The weight loss rates in the first two peaks increased as the WMB-340 ratio increased, whereas it decreased in the third peak. Meanwhile, the $T_{p}, T_{i}$ and $T_{b}$ of the WMB-340 and AC blends decreased as the WMB-340 percentage increased (Table 2). The weight loss in the first and second combustion stages were due to the decomposition of volatiles in the WMB-340. These volatiles were burned before the $\mathrm{AC}$ and the released heat could preheat the coal and 
promote the evaporation of the volatiles in coal, which resulted in the decrease of $T_{i}$ of the WMB-340 and AC blend. The shift of $T_{p}$ to a lower temperature indicated that the cocombustion took place at a relatively low temperature, as evidenced by the $R_{0.5}$ values.
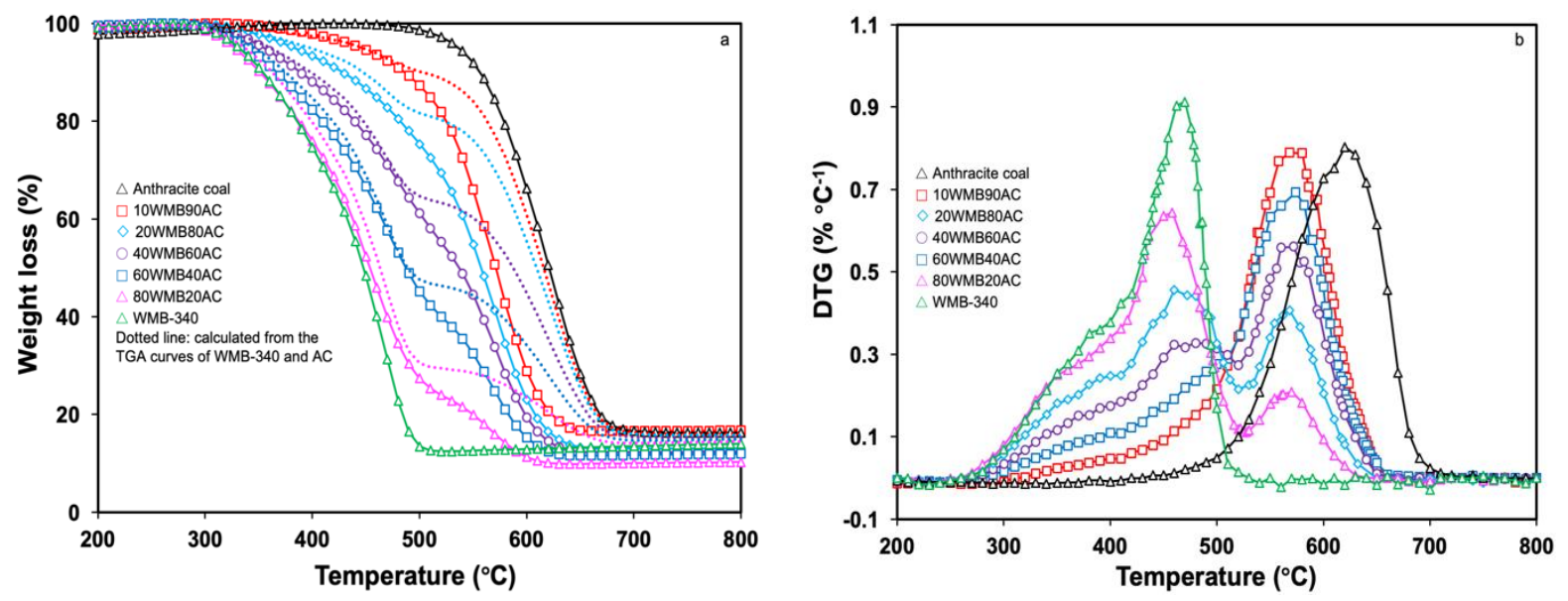

Fig. 3. (a) TGA and (b) DTG curves of anthracite coal, WMB340 and their blends

According to the combustion curves of the WMB and AC blends, it was shown that the combustion process became complicated after blending. To clarify whether a synergistic effect existed between WMB-340 and AC, theoretical TGA curves were calculated based on their experimental data according to Eq. 8,

$$
x_{\text {calculated }}=a \cdot x \mathrm{WMB}+b \cdot x_{\mathrm{AC}}
$$

where $a$ and $b$ were the weight percentages of WMB-340 and AC in the blend, respectively. It was observed that synergistic combustion interactions between WMB-340 and AC existed in the co-combustion process. The calculated curve showed a good fit with the experimental curve at temperatures under $490{ }^{\circ} \mathrm{C}$. However, the calculated curve was obvious higher than the experimental curve when the temperature increased to higher than $490{ }^{\circ} \mathrm{C}$, which indicated the promotion of AC combustion by WMB-340. In addition, the inflection point matched well with the mass ratio of WMB-340 in the blend, and the temperature was a slight lower than the burnout temperature of WMB-340. The promotion of AC combustion was likely due to the participation of volatiles in WMB-340, which had a lower ignition temperature than AC. A large amount of heat was emitted after combustion of volatiles in WMB-340, which promoted the combustion of $\mathrm{AC}$, resulting in greater weight loss at the same temperature compared to burning $\mathrm{AC}$ alone.

\section{Combustion Kinetics of Wood Meal and WMB as well as WMB-340 and Anthracite Coal Blends}

The kinetic parameters of the wood meal, AC, WMB, and WMB-340 and AC blend were calculated based on their TGA curves. As shown on Table 3, the correlation coefficients of the wood meal and WMB in the first combustion stage ranged from 0.76 to 0.89 . The activation energy of wood meal in the first combustion stage was calculated to be $109.9 \mathrm{~kJ} \mathrm{~mol}^{-1}$, higher than those of WMB (91.9 to $\left.105.6 \mathrm{~kJ} \mathrm{~mol}^{-1}\right)$. 
Table 3. Kinetic Parameters of Wood Meal, Wood Meal Biochar, Anthracite Coal, and Wood Meal Biochar Blends

\begin{tabular}{|c|c|c|c|c|c|}
\hline Sample & Temperature Range $\left({ }^{\circ} \mathrm{C}\right)$ & $A_{1}\left(\mathrm{~s}^{-1}\right)$ & $E\left(\mathrm{~kJ} \mathrm{~mol}^{-1}\right)$ & $n(-)$ & $r^{2}(-)$ \\
\hline \multirow{2}{*}{ Wood meal } & $215-395$ & $1.8 \times 10^{7}$ & 109.9 & 1.17 & 0.76 \\
\hline & $395-499$ & $1.6 \times 10^{3}$ & 79.6 & 0.5 & 0.9 \\
\hline \multirow{2}{*}{ WMB-240 } & $219-395$ & $3.3 \times 10^{6}$ & 102.8 & 1.07 & 0.79 \\
\hline & $395-509$ & $3.0 \times 10^{4}$ & 96.1 & 0.68 & 0.94 \\
\hline \multirow{2}{*}{ WMB-260 } & $230-398$ & $2.0 \times 10^{6}$ & 101.9 & 0.97 & 0.77 \\
\hline & $398-509$ & $1.1 \times 10^{5}$ & 104.4 & 0.69 & 0.96 \\
\hline \multirow{2}{*}{ WMB-280 } & $228-398$ & $3.0 \times 10^{6}$ & 104.6 & 0.95 & 0.81 \\
\hline & $398-509$ & $1.8 \times 10^{5}$ & 107.1 & 0.71 & 0.97 \\
\hline \multirow{2}{*}{ WMB-300 } & $243-400$ & $1.8 \times 10^{5}$ & 93.5 & 0.59 & 0.85 \\
\hline & $400-514$ & $1.8 \times 10^{5}$ & 107.2 & 0.74 & 0.96 \\
\hline \multirow{2}{*}{ WMB-320 } & $266-400$ & $1.1 \times 10^{5}$ & 91.9 & 0.42 & 0.89 \\
\hline & $400-514$ & $9.8 \times 10^{5}$ & 117 & 0.78 & 0.94 \\
\hline \multirow{2}{*}{ WMB-340 } & $269-400$ & $1.5 \times 10^{6}$ & 105.6 & 0.47 & 0.88 \\
\hline & $400-522$ & $1.3 \times 10^{6}$ & 118.8 & 0.86 & 0.9 \\
\hline Anthracite coal & $436-737$ & $1.3 \times 10^{8}$ & 179.3 & 1.13 & 0.95 \\
\hline $10 \%$ WMB $90 \%$ AC & $314-666$ & $3.6 \times 10^{2}$ & 84.5 & 0.7 & 0.94 \\
\hline \multirow{3}{*}{$20 \%$ WMB $80 \%$ AC } & $283-400$ & $4.0 \times 10^{5}$ & 99.2 & 0.39 & 0.89 \\
\hline & $400-510$ & 3.9 & 47.6 & 0.03 & 1 \\
\hline & $510-668$ & $1.2 \times 10^{3}$ & 90.6 & 0.8 & 0.97 \\
\hline \multirow{3}{*}{$40 \%$ WMB $60 \%$ AC } & $272-400$ & $3.3 \times 10^{5}$ & 98.1 & 0.43 & 0.89 \\
\hline & $400-520$ & 1.6 & 42.1 & 0.19 & 0.89 \\
\hline & $520-653$ & $6.0 \times 10^{2}$ & 85.8 & 0.73 & 0.97 \\
\hline \multirow{3}{*}{$60 \%$ WMB $40 \%$ AC } & $265-400$ & $5.4 \times 10^{5}$ & 100.2 & 0.51 & 0.89 \\
\hline & $400-524$ & 3 & 44.8 & 0.38 & 0.72 \\
\hline & $520-649$ & $2.2 \times 10^{3}$ & 93.8 & 0.76 & 0.94 \\
\hline \multirow{3}{*}{$80 \%$ WMB $20 \%$ AC } & $262-400$ & $2.4 \times 10^{5}$ & 95.6 & 0.48 & 0.9 \\
\hline & $400-525$ & 9 & 49.4 & 0.58 & 0.83 \\
\hline & $525-640$ & $2.4 \times 10^{4}$ & 109.6 & 0.82 & 0.86 \\
\hline
\end{tabular}

The results indicated that lower energy was needed to initialize the first combustion stage of WMB, due to the destruction of the crystalline structure in cellulose. As aforementioned, the weight loss in the first combustion stage was primarily ascribed to the combustion of holocellulose. However, the activation energies of wood meal and WMB in the first combustion stage were much lower than those of cellulose and hemicellulose, with values of 239.9 and $166.4 \mathrm{~kJ} \mathrm{~mol}^{-1}$, respectively (Yu et al. 2015). The lower activation energies of wood meal and WMB were likely caused by the adsorption of the decomposition products from cellulose and hemicellulose on lignin and char, which could accelerate the deoxygenating reactions (Fushimi et al. 2009). The coefficients of determination in the second combustion stage were much higher than those in the first combustion stage, with values ranged from 0.9 to 0.97 . The activation energy of wood meal in the second combustion stage was $79.6 \mathrm{~kJ} \mathrm{~mol}^{-1}$, which was lower than those of WMB (96 to $118.8 \mathrm{~kJ} \mathrm{~mol}^{-1}$ ). It also yielded a lower value than in the first combustion stage. However, the activation energy of WMB in the second combustion stage increased as the torrefaction temperature increased, and it became higher than that in the first combustion stage when the torrefaction temperature was above $240{ }^{\circ} \mathrm{C}$. The higher activation energy 
in the second combustion study implied the increased difficulty in starting the reaction. The activation energies of WMB in the second combustion stage were much lower than those of alkali lignin (124 to $721 \mathrm{~kJ} \mathrm{~mol}^{-1}$ ), fir lignin $\left(136.9 \mathrm{~kJ} \mathrm{~mol}^{-1}\right)$, and Klason lignin $\left(166.2 \mathrm{~kJ} \mathrm{~mol}^{-1}\right)$, due to the destruction of aromatic structures in lignin during torrefaction (Ma et al. 2016). The pre-exponential factors in the first and second combustion stages ranged from $1.1 \times 10^{5}$ to $1.8 \times 10^{7} \mathrm{~s}^{-1}$ and $1.6 \times 10^{3}$ to $1.3 \times 10^{6} \mathrm{~s}^{-1}$, respectively. The reaction orders were from 0.42 to 1.17 and 0.5 to 0.86 for the first and second combustion stages, respectively.

The combustion kinetics drastically changed when AC was blended with WMB340. The activation energy of $\mathrm{AC}$ was $179.3 \mathrm{~kJ} \mathrm{~mol}^{-1}$, and it decreased after being blended with 10\% WMB-340 (84.5 kJ mol$\left.{ }^{-1}\right)$. The temperature ranges of the first and second combustion stages of the blends were similar to those of WMB-340; however, the activation energies were lower than those of WMB-340, which was ascribed to the synergistic effect between $\mathrm{WMB}$ and $\mathrm{AC}$. The activation energies of the above blends in the third combustion stage were also much lower than that of $\mathrm{AC}$, due to the releasing of heat from WMB-340 at low temperatures. The above results suggested that the blending of WMB-340 greatly reduced the barrier for AC combustion. The correlation coefficients, pre-exponential factors, and reaction orders of $\mathrm{AC}$ and its blends were calculated to be among 0.72 to $1,1.6$ to $1.3 \times 10^{8} \mathrm{~s}^{-1}$ and 0.03 to 1.13 , respectively. Among all the $\mathrm{AC}$ and WMB-340 blends in the present study, it was considered that the blend containing $10 \%$ WMB-340 was the optimal composition for co-combustion, due to the lower activation energy and similar combustion characteristics when compared with those of AC.

\section{CONCLUSIONS}

1. The wood meal biochar prepared by dry torrefaction had excellent fuel properties. Although the energy yield of biochar decreased as the torrefaction temperature increased, it still remained as high as $78.6 \%$, even at $340{ }^{\circ} \mathrm{C}$.

2. The WMB-340 showed similar HHV to commercial coal and was chosen to cocombust with $\mathrm{AC}$. The combustion reactivity of $\mathrm{AC}$ was efficiently promoted by being blended with WMB-340, and the $T_{p}, T_{i}$, and $T_{b}$ of AC shifted to lower temperatures.

3. Anthracite coal blended with $10 \%$ WMB-340 had no obvious change in its combustion stage. However, three combustion stages were observed when more than $10 \%$ of WMB-340 was blended with AC. The blend containing 10\% WMB-340 showed similar combustion characteristics and a lower activation energy compared with AC alone, which suggested that this blend was the optimal composition for co-combustion.

\section{ACKNOWLEDGMENTS}

The authors are grateful for the support of the Zhejiang Province Nature Science Foundation of China (Grant Nos. LQ19B060009 and LY19E060003) and the Key R\&D Program Projects in Zhejiang Province, China (Grant No. 2019C02063). A portion of this work was supported by the Zhejiang Province Key Laboratory of Smart Management and Application of Modern Agricultural Resources under grant 2020E10017. 


\section{REFERENCES CITED}

Boon, J. J., Pastrova, I., Botto, R. E., and Arisz, P. W. (1994). "Structural studies on cellulose pyrolysis and cellulose char by PYMS, PYGVMS, FTIR, NMR and by wet chemical techniques," Biomass and Bioenergy 7(1-6), 25-32. DOI: 10.1016/09619534(94)00044-T

Chen, W. H., Huang, M. Y., Chang, J. S., and Chen, C. Y. (2015). "Torrefaction operation and optimization of microalga residue for energy densification and utilization," Applied Energy 154, 622-630. DOI: 10.1016/j.apenergy.2015.05.068

Dai, L. L., Wang, Y. P., Liu, Y. H., Ruan, R., He, C., Yu, Z. T., Jiang, L., Zeng, Z. H., and Tian, X. J. (2019). "Integrated process of lignocellulosic biomass torrefaction and pyrolysis for upgrading bio-oil production: A state-of-the-art review," Renewable and Sustainable Energy Reviews 107, 20-36. DOI: 10.1016/j.rser.2019.02.015

Fu, B., Liu, G. J., Mian, Md., M., Sun, M., and Wu, D. (2019). "Characteristics and speciation of heavy metals in fly ash and FGD gypsum from Chinese coal-fired power plants," Fuel 251, 593-602. DOI: 10.1016/j.fuel.2019.04.055

Fushimi, C., Katayama, S., and Tsutsumi, A. (2009). "Elucidation of interaction among cellulose, lignin and xylan during tar and gas evolution in steam gasification," $J$. Analytical and Applied Pyrolysis 86(1), 82-89. DOI: 10.1016/j.jaap.2009.04.008

Gan, Y. Y., Ong, H. C., Ling, T. C., Chen, W. H., and Chong, C. T. (2019). "Torrefaction of de-oiled Jatropha seed kernel biomass for solid fuel production," Energy 170, 367374. DOI: 10.1016/j.energy.2018.12.026

He, X. Y., Liu, Z. X., Niu, W. J., Yang, L., Zhou, T., Qin, D., and Niu, Z. Y. (2018). "Effects of pyrolysis temperature on the physicochemical properties of gas and biochar obtained from pyrolysis of crop residues," Energy 143, 746-756. DOI: 10.1016/j.energy.2017.11.062

Huang, N., Zhao, P., Ghosh, S., and Fedyukhin, A. (2019). “Co-hydrothermal carbonization of polyvinyl chloride and moist biomass to remove chlorine and inorganics for clean fuel production," Applied Energy 240, 882-892. DOI: 10.1016/j.apenergy.2019.02.050

Khan, A. A., de Jong, W., Jansens, P. J., and Spliethoff, H. (2009). "Biomass combustion in fluidized bed boiler: Potential problems and remedies," Fuel Processing Technology 90(1), 21-50. DOI: 10.1016/j.fuproc.2008.07.012

Liu, Z., Hu, W., Jiang, Z., Mi, B., and Fei, B. (2016). "Investigating combustion behaviors of bamboo, torrefied bamboo, coal and their respective blends by thermogravimetric analysis," Renewable Energy 87(Part 1), 346-352. DOI: 10.1016/j.renene.2015.10.039

Li, J., Yang, W., Blasiak, W., and Ponzio, A. (2012). "Volumetric combustion of biomass for $\mathrm{CO}_{2}$ and $\mathrm{NO}_{\mathrm{x}}$ reduction in coal-fired boilers," Fuel 102, 64-633. DOI: 10.1016/j.fuel.2012.06.083

Li, Y. H., Lin, H. T., Xiao, K. L., and Lasek, J. (2018). “Combustion behavior of coal pellets blended with Miscanthus biochar,” Energy 163, 180-190. DOI: 10.1016/j.energy.2018.08.117

Li, M. F., Chen, L. X., Li, X., Chen, C. Z., Lai, Y. C., Xiao, X., and Wu, Y. Y. (2016). "Evaluation of the structure and fuel properties of lignocelluloses through carbon dioxide torrefaction," Energy Conversion and Management 119, 463-472. DOI: 10.1016/j.enconman.2016.04.064

Lu, J. J., and Chen, W. H. (2015). "Investigation on the ignition and burnout 
temperatures of bamboo and sugarcane bagasse by thermogravimetric analysis," Applied Energy 160, 49-57. DOI: 10.1016/j.apenergy.2015.09.026

Mahinpey, N., Murugan, P., Mani, T., and Raina, R. (2009). "Analysis of bio-oil, biogas, and biochar from pressurized pyrolysis of wheat straw using a tubular reactor," Energy \& Fuels 23(5), 2736-2742. DOI: 10.1021/ef8010959

Ma, Z., Sun, Q., Ye, J., Yao, Q., and Zhao, C. (2016). "Study on the thermal degradation behaviors and kinetics of alkali lignin for production of phenolic-rich bio-oil using TGA-FTIR and Py-GC/MS," Journal of Analytical and Applied Pyrolysis 117, 116124. DOI: 10.1016/j.jaap.2015.12.007

Ouyang, Z. Q., Zhu, J. G., and Lu, Q. G. (2013). "Experimental study on preheating and combustion characteristics of pulverized anthracite coal," Fuel 113, 122-127, DOI: 10.1016/j.fuel.2013.05.063

Pang, S. S. (2019). "Advances in thermochemical conversion of woody biomass to energy, fuels and chemicals," Biotechnology Advances 37, 589-597. DOI: 10.1016/j.biotechadv.2018.11.004

Poulsen, T. G., and Adelard, L. (2016). "Improving biogas quality and methane yield via co-digestion of agricultural and urban biomass wastes," Waste Management 54, 118125. DOI: 10.1016/j.wasman.2016.05.020

Rover, M., Smith, R., and Brown, R. C. (2018). "Enabling biomass combustion and cofiring through the use of Lignocal," Fuel 211, 312-317. DOI: 10.1016/j.fuel.2017.09.076

Qian, C., Li, Q. B., Zhang, Z. Z., Wang, X. F., Hu, J. C., and Cao, W. J. (2020). "Prediction of higher heating values of biochar from proximate and ultimate analysis," Fuel 265, 116925. DOI: 10.1016/j.fuel.2019.116925

Sahu, S. G., Sarkar, P., Chakraborty, N., and Adak, A. K. (2010). "Thermogravimetric assessment of combustion characteristics of blends of a coal with different biomass chars," Fuel Processing Technol. 91(3), 369-378. DOI: 10.1016/j.fuproc.2009.12.001

Toptas, A., Yildirim, Y., Duman, G., and Yanik, J. (2015). "Combustion behavior of different kinds of torrefied biomass and their blends with lignite," Bioresource Technology 177, 328-336. DOI: 10.1016/j.biortech.2014.11.072

Wang, P., Wang, G., Zhang, J., Lee, J. Y., Li, Y., and Wang, C. (2018). "Co-combustion characteristics and kinetic study of anthracite coal and palm kernel shell char," Appl. Thermal Engineering 143, 736-745. DOI: 10.1016/j.applthermaleng.2018.08.009

Yang, W., Wang, H., Zhou, J., and Wu, S. (2017). "Hydrolysis kinetics and structure changes of wood meal in subcritical water," ACS Sustainable Chemistry \& Engineering 5(4), 3544-3552. DOI: 10.1021/acssuschemeng.7b00300

Yang, W., Fang, M., Xu, H., Wang, H., Wu, S., Zhou, J., and Zhu, S. (2019). "Interactions between holocellulose and lignin during hydrolysis of sawdust in subcritical water," ACS Sustainable Chemistry \& Engineering 7(12), 10583-10594. DOI: 10.1021/acssuschemeng.9b01127

Yu, H., Liu, F., Ke, M., and Zhang, X. (2015). "Thermogravimetric analysis and kinetic study of bamboo waste treated by Echinodontium taxodii using a modified threeparallel-reactions," Bioresource Technology 185, 324-330. DOI: 10.1016/j.biortech.2015.03.005

Article submitted: August 14, 2020; Peer review completed: October 25, 2020; Revised version received and accepted: December 14, 2020; Published: December 16, 2020. DOI: 10.15376/biores.16.1.997-1008 